\title{
Pharmacophore and Atom Based 3D QSAR Studies on the Novel 5-Alpha-Reductase Inhibitors
}

\author{
Abhishek Shah", Richard Lobo ${ }^{1 *}$, Nandakumar Krishnadas ${ }^{2}$, Aravinda Pai ${ }^{3}$ \\ ${ }^{1}$ Department of Pharmacognosy, Manipal College of Pharmaceutical Sciences, Manipal Academy for Higher Education, \\ Manipal - 576104, Karnataka, INDIA. \\ ${ }^{2}$ Department of Pharmacology, Manipal College of Pharmaceutical Sciences, Manipal Academy for Higher Education, Manipal - 576104, \\ Karnataka, INDIA. \\ ${ }^{3}$ Department of Pharmaceutical Chemistry, Manipal College of Pharmaceutical Sciences, Manipal Academy for Higher Education, \\ Manipal - 576104, Karnataka, INDIA.
}

\begin{abstract}
Aim/Background: The anomalous production of dihydrotestosterone (DHT) observed in benign prostatic hyperplasia and prostate cancer particularly in tissues of the prostate gland. The primary male sex hormone, testosterone $(T)$ is improved to a metabolite in cells by $5 a$-reductase ( $5 a R)$ type II enzyme through NADPH. A metabolite is DHT which is more potent than T. Drug therapy is the best alternative for the treatment of benign prostatic hyperplasia (BPH). Drug therapy act by dropping the DHT formation through inhibiting the $5 \mathrm{aR}$ enzyme. Thus, this research work was undertaken to design a novel $5 \mathrm{aR}$ enzyme inhibitor by pharmacophore and Atom-based 3D QSAR technique. Materials and Methods: A dataset of twenty-nine ligands available with IC 50 chosen from the literature. Schrodinger molecular modelling software is having, phase 3.0 module implicated for generation of pharmacophore models. Results: Pharmacophore hypothesis with five features having two $\mathrm{H}$-bond acceptors and three hydrophobic group was developed, i.e., AAHHH.715. This Pharmacophore hypothesis regarded as the finest one. This hypothesis resulted into statistically significant three-dimensional QSAR model. The statistical parameters were found to be 0.9804 as $r 2$ value and 0.8321 as q 2 value. Out of 29 ligands, 23 ligands assigned as training set and 6 ligands as a test set. The squared correlation coefficient between training and test sets based on actual and predicted values were observed to be 0.96 and 0.87 respectively. Conclusion: The $5 \mathrm{aR}$ enzyme inhibitors predicting requirements can be done by this built model.
\end{abstract}

Key words: 5-alpha reductase, Pharmacophore, QSAR, DHT, BPH.

\section{INTRODUCTION}

Male secondary sex organs development and maintenance of secretory function are dependent on androgens. The androgen found most abundantly in serum is testosterone ( $T$ ), produced by Leydig cells in testes controlled by the hypothalamus and pituitary gland., 2 The $\mathrm{T}$ is improved to a metabolite in cells by 5a-reductase type II enzyme through NADPH. A metabolite is a dihydrotestosterone (DHT) which is more potent than $\mathrm{T}^{3}$ The $5 \mathrm{a}$-reductase $(5 \mathrm{aR})$ isozymes are type I (5aR1) and type II (5aR2) identified by molecular cloning. ${ }^{4}$ The distribution of $5 \mathrm{aR}$ is skin, kidney, liver and lungs have $5 \mathrm{aR} 1$ whereas $5 \mathrm{aR} 2$ is found in prostate, seminal vesicle, epididymis and hair follicles. ${ }^{5}$ The anomalous production of DHT observed in $\mathrm{BPH}$ and prostate cancer particularly in prostate tissue. ${ }^{6,7} \mathrm{BPH}$ has majorly two treatments available such as surgery and drug therapy. Clinically operation is effectual, but economical and postoperative complications are factors which limit it., Pharmacological (Drug) therapy, hence is the best alternative for the treatment of BPH. Drug therapy act by dropping the DHT formation through inhibiting the $5 \mathrm{aR}$ enzyme. Thus, a strategy proposed for
Submission Date: 20-06-2018; Revision Date: 14-08-2018; Accepted Date: 23-10-2018

DOI: 10.5530/ijper.52.4s.110 Correspondence: Dr. Richard Lobo, Associate Professor (Senior Scale), Department of Pharmacognosy, Manipal College of Pharmaceutical Sciences, Manipal Academy for Higher Education,

Manipal-576 104, Karnataka, INDIA.

Phone no: 09448104090 E-mail: richardlobo73@ gmail.com

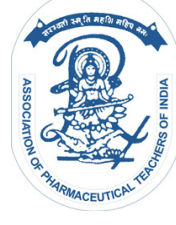

www.ijper.org 
controlling levels of DHT in the prostate by restricting $5 \mathrm{aR}$ activity (i.e., hindering the formation of DHT from T) ${ }^{10}$ In due course of time, various potential $5 \mathrm{aR}$ inhibitors have synthesized and the even large number investigated. Some steroidal 5aR inhibiting molecules with higher binding affinities have produced which produces greater inhibition. ${ }^{11}$ Commercially, finasteride ${ }^{12}$ and epristeride ${ }^{13}$ used as treatment options for BPH. These steroidal molecules have hormonal adverse effects. ${ }^{14}$ Thus, nonsteroidal inhibitors are developed to overcome these adverse effects, but the activity of non-steroidal molecules as $5 \mathrm{aR}$ inhibition remain less. ${ }^{15-18}$ Apart from this, there are only a few drugs available to treat prostate diseases and existing drugs are becoming resistant. So, there is an urgent need for a drug which is highly specific and less toxic. Hence, this research work was undertaken to design a novel $5 \mathrm{aR}$ enzyme inhibitor by pharmacophore and Atom-based 3D QSAR technique.

\section{MATERIAL AND METHODS}

\section{Data set selection}

A dataset of twenty-nine ligands available with IC 50 for $5 \mathrm{aR}$ chosen from literature. Out of 29 ligands, 23 ligands assigned as training set and 6 ligands as test set. $^{19,20}$ The model built by a training set and validation performed by the test set. The activity data, i.e. IC 50 values collected from the literature were transformed to PIC50 by choices present in the calculator.

\section{Pharmacophore hypothesis generation:}

Schrodinger molecular modeling software is having, Phase 3.0 module implicated for production of pharmacophore models. The minimum energy structural feature is required, to attain exact 3D descriptor values associated with QSAR studies. Maestro 2D sketch was used to draw the structures and these 2D structures converted to their respective 3D structures. OPLS force field was used to perform the geometry optimization. Two sets were formed, namely, training and test sets, of all ligands.

PHASE uses a structure cleaning utility called ligprep, which adds hydrogen, generates stereoisomers and various conformers and predicts proper ionization states at a particular PH.PHASE provides two inbuilt approaches, employing the MacroModel conformational search engine. Due to the flexibility of ligands, all the possible conformers observed for each set of ligands and conformers close to the crystal structures could be sorted out. The conformational analysis was carried out using Monte Carlo Multiple Minimum methods.
The ligands were separated on the basis of the activity threshold value into active and inactive sets. ${ }^{21}$

\section{Creation of Pharmacophore sites}

Five-point pharmacophoric features defined the local chemical environment of selected ligands such as two H-bond acceptors (A) and three hydrophobic group $(\mathrm{H})$. The inter-site distance and angles were used to develop pharmacophore.

\section{Scoring pharmacophores on the basis of their activity threshold}

The scoring and ranking of pharmacophore done to identify the best pharmacophore hypothesis. The configuration of site points and magnitude of vectors, selectivity and activity with overall conformational energies was considered to be active contributions for the scoring algorithm.

\section{Identifying common pharmacophores}

Once, the best hypothesis, AAHHH (Figure 1A) selection is over, afterward, it was further analyzed (Table 1). The best hypothesis is the Pharmacophore, i.e. AAHHH. The pharmacophore, in this case, has unique characteristics as $\mathrm{AA}$, i.e. two hydrogen bond acceptor and $\mathrm{HHH}$, i.e. three hydrophobic groups. Pink sphere represents A with two arrows and $\mathrm{H}$ by green spheres (Figure 1B). Table 2 and Table 3 represents site scores of distances and angles respectively.

\section{Building QSAR models}

QSAR model was developed based on a selected common hypothesis by segregating the literature data into a training set as 70\% and test set as 30\% based on activity, structural similarity and functional group variation. PHASE provides binary options for the geometric alignment of 3 dimensional structures. In the present study, an Atombased QSAR model used and this technique is a useful tool for the study of structure-activity relationships. The

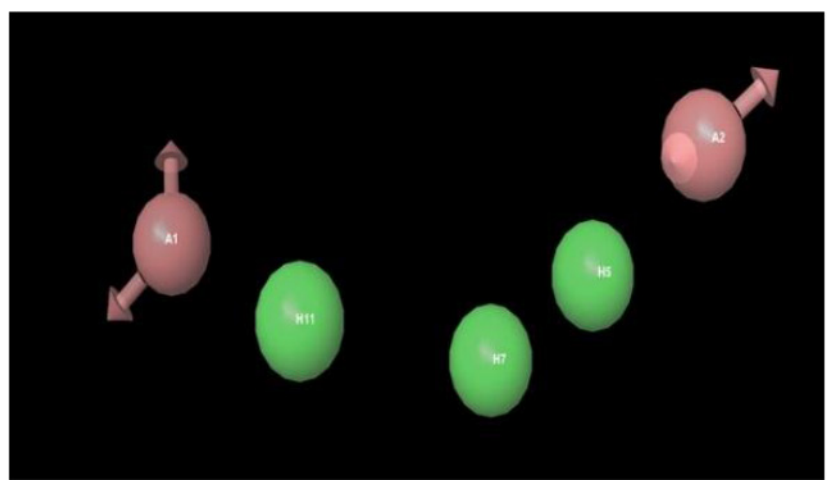

Figure 1: a. Common hypothesis. 


\begin{tabular}{|c|c|c|c|c|c|c|c|c|c|c|}
\hline In & ID & Survival & $\begin{array}{l}\text { Survival } \\
\text {-inactive }\end{array}$ & Site & Vector & Volume & $\begin{array}{c}\# \\
\text { Matches }\end{array}$ & Energy & Activity & Inactive \\
\hline 0 & ААННН.715 & 4.917 & 3.307 & 0.5 & 0.932 & 0.629 & 12 & 0 & 7.62 & 1.61 \\
\hline 0 & ААННН.669 & 4.917 & 3.307 & 0.5 & 0.932 & 0.629 & 12 & 0 & 7.62 & 1.61 \\
\hline 0 & ААННН.371 & 4.917 & 3.307 & 0.5 & 0.932 & 0.629 & 12 & 0 & 7.62 & 1.61 \\
\hline 0 & ААННН.325 & 4.917 & 3.307 & 0.5 & 0.932 & 0.629 & 12 & 0 & 7.62 & 1.61 \\
\hline 0 & ААННН.721 & 4.913 & 3.311 & 0.51 & 0.928 & 0.624 & 12 & 0 & 8.284 & 1.602 \\
\hline 0 & ААННН.675 & 4.913 & 3.311 & 0.51 & 0.928 & 0.624 & 12 & 0 & 8.284 & 1.602 \\
\hline 0 & ААННН.377 & 4.913 & 3.311 & 0.51 & 0.928 & 0.624 & 12 & 0 & 8.284 & 1.602 \\
\hline 0 & ААННН.331 & 4.913 & 3.311 & 0.51 & 0.928 & 0.624 & 12 & 0 & 8.284 & 1.602 \\
\hline 0 & ААННН.272 & 4.834 & 3.199 & 0.49 & 0.896 & 0.593 & 12 & 0 & 7.62 & 1.634 \\
\hline 0 & AАHНH.606 & 4.834 & 3.199 & 0.49 & 0.896 & 0.593 & 12 & 0 & 7.62 & 1.634 \\
\hline
\end{tabular}

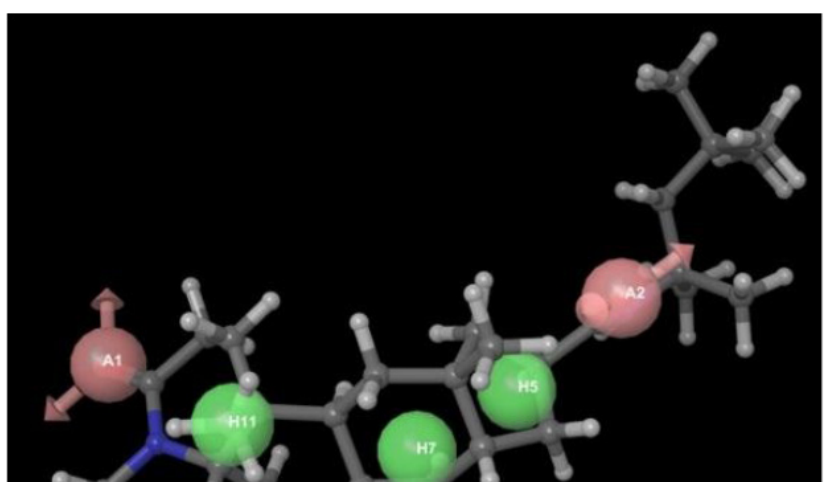

Figure 1: b. Common hypothesis on active molecule.

\begin{tabular}{|c|c|c|c|}
\hline Entry & Site1 & Site2 & Distance \\
\hline ААННН.715 & $\mathrm{A} 1$ & $\mathrm{~A} 2$ & 10.851 \\
\hline ААННН.715 & $\mathrm{A} 1$ & $\mathrm{H} 5$ & 8.677 \\
\hline ААННН.715 & A1 & $\mathrm{H} 7$ & 7.042 \\
\hline AАНHН.715 & $\mathrm{A} 1$ & $\mathrm{H} 11$ & 5.118 \\
\hline ААННН.715 & $\mathrm{A} 2$ & $\mathrm{H} 5$ & 2.796 \\
\hline AАHНH.715 & $\mathrm{A} 2$ & $\mathrm{H} 7$ & 5.077 \\
\hline ААННН.715 & $\mathrm{A} 2$ & $\mathrm{H} 11$ & 8.16 \\
\hline ААННН.715 & H5 & $\mathrm{H} 7$ & 2.352 \\
\hline ААННН.715 & $\mathrm{H} 5$ & $\mathrm{H} 11$ & 5.935 \\
\hline AAHHH.715 & $\mathrm{H} 7$ & $\mathrm{H} 11$ & 3.98 \\
\hline
\end{tabular}

group of overlying van der Waal's spheres considered for every molecule in the study of atom based QSAR. Each atom placed into one of the three categories like positive ionic interactions, negative ionic interactions and hydrophobic non-polar interactions. The training set ligands arranged in regular Grid of cubes to develop

\begin{tabular}{|c|c|c|c|c|}
\hline Entry & Site1 & Site2 & Site3 & Angle \\
\hline ААННН.715 & $\mathrm{A} 2$ & A1 & H5 & 10.4 \\
\hline ААННН.715 & A2 & A1 & $\mathrm{H} 7$ & 22.1 \\
\hline ААННН.715 & $\mathrm{A} 2$ & A1 & H11 & 45.9 \\
\hline ААННН.715 & H5 & A1 & $\mathrm{H} 7$ & 12.4 \\
\hline ААННН.715 & H5 & A1 & $\mathrm{H} 11$ & 41.8 \\
\hline ААННН.715 & $\mathrm{H} 7$ & A1 & $\mathrm{H} 11$ & 33.7 \\
\hline ААННН.715 & A1 & A2 & H5 & 34 \\
\hline ААННН.715 & A1 & A2 & $\mathrm{H} 7$ & 31.5 \\
\hline ААННН.715 & A1 & A2 & $\mathrm{H} 11$ & 26.7 \\
\hline ААННН.715 & H5 & A2 & $\mathrm{H} 7$ & 8.7 \\
\hline ААННН.715 & H5 & A2 & $\mathrm{H} 11$ & 30.8 \\
\hline ААННН.715 & $\mathrm{H} 7$ & A2 & H11 & 22.6 \\
\hline ААННН.715 & A1 & H5 & $\mathrm{A} 2$ & 135.6 \\
\hline ААННН.715 & A1 & H5 & $\mathrm{H} 7$ & 40.1 \\
\hline ААННН.715 & A1 & H5 & $\mathrm{H} 11$ & 35.1 \\
\hline ААННН.715 & A2 & H5 & $\mathrm{H} 7$ & 160.9 \\
\hline ААННН.715 & $\mathrm{A} 2$ & H5 & $\mathrm{H} 11$ & 135.2 \\
\hline ААННН.715 & $\mathrm{H} 7$ & H5 & $\mathrm{H} 11$ & 26.8 \\
\hline ААННН.715 & A1 & $\mathrm{H} 7$ & A2 & 126.4 \\
\hline ААННН.715 & A1 & $\mathrm{H} 7$ & H5 & 127.5 \\
\hline ААННН.715 & A1 & $\mathrm{H} 7$ & $\mathrm{H} 11$ & 45.6 \\
\hline ААННН.715 & A2 & $\mathrm{H} 7$ & H5 & 10.4 \\
\hline ААННН.715 & A2 & $\mathrm{H} 7$ & H11 & 128.2 \\
\hline ААННН.715 & H5 & $\mathrm{H} 7$ & $\mathrm{H} 11$ & 137.7 \\
\hline ААННН.715 & A1 & H11 & A2 & 107.4 \\
\hline ААННH.715 & A1 & $\mathrm{H} 11$ & $\mathrm{H} 5$ & 103.2 \\
\hline ААННН.715 & A1 & $\mathrm{H} 11$ & $\mathrm{H} 7$ & 100.7 \\
\hline ААННН.715 & $\mathrm{A} 2$ & $\mathrm{H} 11$ & H5 & 14 \\
\hline ААННН.715 & $\mathrm{A} 2$ & $\mathrm{H} 11$ & $\mathrm{H} 7$ & 29.3 \\
\hline ААННН.715 & H5 & H11 & $\mathrm{H} 7$ & 15.5 \\
\hline
\end{tabular}


best fit QSAR model. The cubes are labeled in a binary bit format to show different atom types and their features. The resulted data can be used to generate a partial least square regression model (PLS). The training set (23) was used to create atom-based QSAR models for the selected hypothesis using three PLS factors. The remaining molecules took under test set. ${ }^{21}$

\section{RESULTS AND DISCUSSION}

Undertaken research work intended to throw light on the three-dimensional structural properties of inhibitors of $5 \mathrm{aR}$. The Phase module was used to carry out the pharmacophore modeling and QSAR studies of Schrodinger suite. This Phase module helps in envisaging the relative binding of test ligands to the active site of the receptor of the generated hypothesis. The pharmacophore dependent alignment was used to create the 3D-QSAR model for identification of structural features needed to inhibit $5 \mathrm{aR}$.
The pharmacophore model generated by considering 29 compounds, having activity against 5-alpha reductase. These compounds have significant structural properties mandatory for binding to the receptor site. The most active compounds identified on the basis of having common properties as four minimum site and five maximum sites. The hypothesis AAHHH (Refer Table 1) was selected based on survival active and inactive scores. This pharmacophore hypothesis implicated in generating 3D QSAR model. Predictive ability of both training and test set implicated in assessing the 3D QSAR model (Table 4). For a given set of PLS factors, the equation was analyzed on the basis of regression coefficient value and crossed validation coefficient value. The QSAR model based on the unique features of the atoms attached to the core ring system. The features studied are positive ionic interactions, negative ionic interactions and hydrophobic non-polar interactions (Figure 2 $\mathrm{a}, \mathrm{b}$ and $\mathrm{c})$.

\begin{tabular}{|c|c|c|c|c|c|c|}
\hline In & Ligand Name & QSAR Set & Activity & \# Factors & Predicted Activity & Prediction Error \\
\hline 0 & alp1 & training & 6.569 & 4 & 6.62627 & 0.057266 \\
\hline 0 & alp4 & training & 6.377 & 2 & 6.3719 & -0.0051 \\
\hline 0 & alp5 & training & 6.77 & 4 & 6.5583 & -0.2117 \\
\hline 0 & alp6 & training & 5.824 & 3 & 5.95404 & 0.13004 \\
\hline 0 & alp10 & training & 7.77 & 4 & 7.78301 & 0.013014 \\
\hline 0 & alp11 & test & 7.959 & 4 & 7.88328 & -0.07572 \\
\hline 0 & alp12 & training & 7.62 & 4 & 7.62856 & 0.008561 \\
\hline 0 & alp13 & training & 7.62 & 4 & 7.59629 & -0.02371 \\
\hline 0 & alp14 & training & 7.398 & 3 & 7.43792 & 0.039915 \\
\hline 0 & alp15 & training & 8.252 & 4 & 8.30671 & 0.054707 \\
\hline 0 & alp16 & training & 8.284 & 1 & 8.29908 & 0.015083 \\
\hline 0 & alp17 & test & 7.699 & 1 & 7.76122 & 0.062225 \\
\hline 0 & alp18 & training & 8 & 4 & 8.02758 & 0.02758 \\
\hline 0 & alp19 & training & 7.824 & 4 & 7.82526 & 0.001256 \\
\hline 0 & alp20 & training & 8.086 & 1 & 8.07192 & -0.01408 \\
\hline 0 & alp21 & test & 6.538 & 4 & 6.27768 & -0.26032 \\
\hline 0 & alp22 & training & 7.699 & 2 & 7.70942 & 0.010416 \\
\hline 0 & alp23 & training & 7.824 & 4 & 7.10512 & 0.051028 \\
\hline 0 & alp25 & training & 5.409 & 3 & 5.39927 & -0.00973 \\
\hline 0 & alp26 & training & 6.081 & 4 & 6.31708 & 0.236083 \\
\hline 0 & alp29 & training & 2.4 & 4 & 7.61106 & 0.018493 \\
\hline 0 & alp2 & test & 6.77 & 4 & 6.73722 & -0.03278 \\
\hline 0 & alp3 & training & 6.824 & 4 & 6.58318 & -0.24082 \\
\hline 0 & alp7 & training & 6.553 & 4 & 6.69828 & 0.145282 \\
\hline 0 & alp8 & test & 7.027 & 2 & 7.45904 & 0.432042 \\
\hline 0 & alp9 & training & 7.398 & 3 & 7.36283 & -0.03517 \\
\hline 0 & alp24 & test & 5.845 & 2 & 6.18911 & 0.344114 \\
\hline 0 & alp27 & training & 6.959 & 4 & 7.04492 & 0.085915 \\
\hline 0 & alp28 & training & 2.2 & 4 & 7.80152 & 0.106814 \\
\hline
\end{tabular}




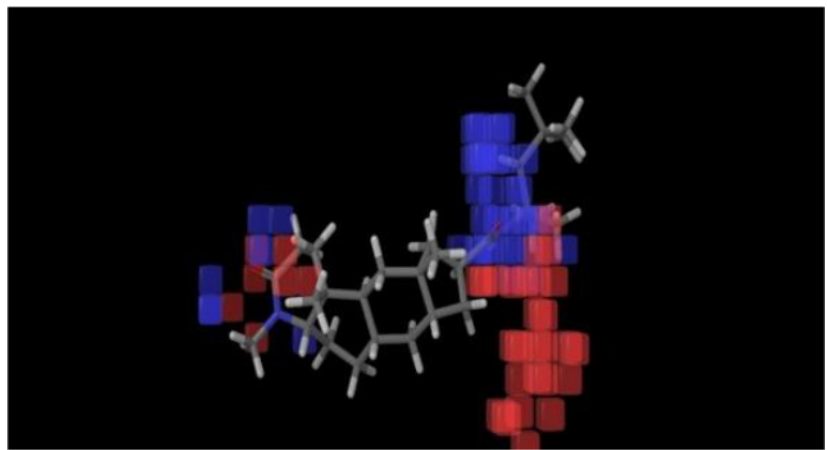

Figure 2: QSAR models for different types of interactions. a. Positive ionic interactions.

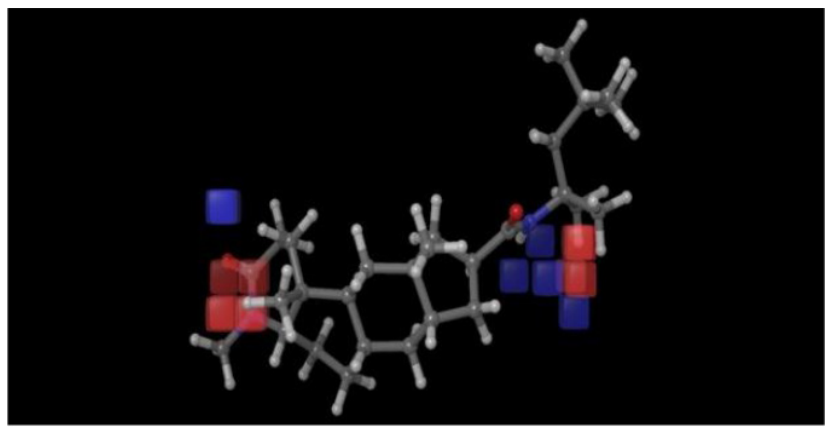

Figure 2: QSAR models for different types of interactions. b. Negative ionic interactions.

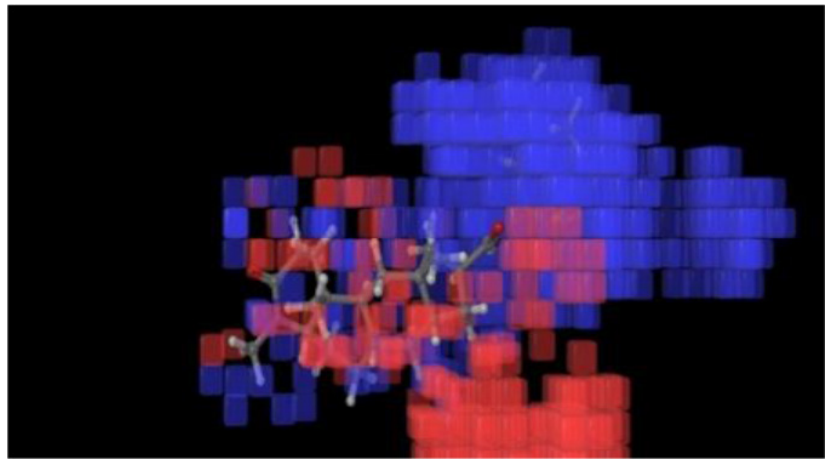

Figure 2: QSAR models for different types of interactions c. Hydrophobic non-polar interactions.

A dataset of twenty-nine ligands available with IC 50 chosen from literature. Pharmacophore hypothesis with five features having two $\mathrm{H}$-bond acceptors and three hydrophobic group developed, i.e. AAHHH.715. This Pharmacophore hypothesis regarded as the finest hypothesis. The hypothesis resulted into statistically significant three-dimensional QSAR model. The statistical parameters were found to be 0.9804 as $^{2}$ value and $0.8321 \mathrm{as} \mathrm{q}^{2}$ value (refer Table 5). The created model was applied effectively on both sets respectively.

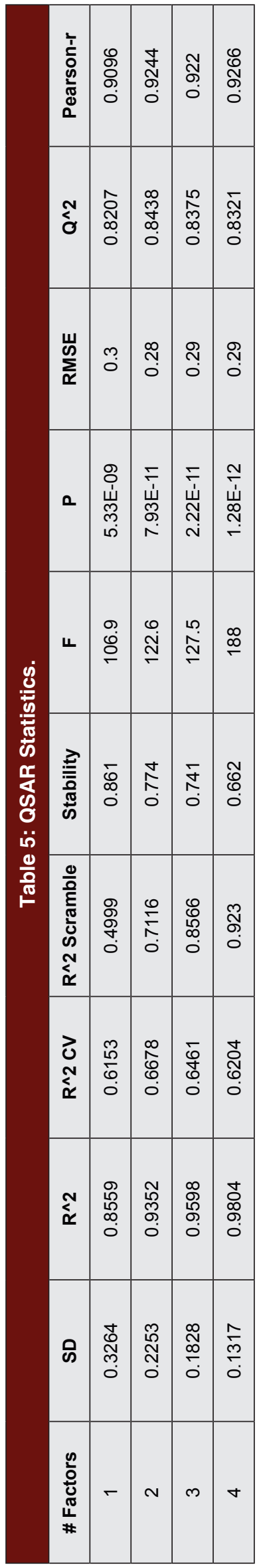


Table 6: Ligand Structures with $I_{50}$ values. $^{19,20}$

\begin{tabular}{|c|c|c|}
\hline Sr. No. & IUPAC Name & $\mathrm{IC}_{50}$ \\
\hline 1 & $\begin{array}{c}\text { 1,4a,6a-Trimethyl-2-oxo- } \mathrm{N} \text {-(2,4,4-trimethyl-2-pentanyl)hexadecahydro-1H-indeno[5,4-f] } \\
\text { quinoline-7-carboxamide }\end{array}$ & $2.7 \mathrm{nM}$ \\
\hline 2 & $\begin{array}{l}\text { 4a,6a-Dimethyl-2-oxo-N-(2,4,4-trimethyl-2-pentanyl)hexadecahydro-1H-indeno[5,4-f]quinoline- } \\
\text { 7-carboxamide }\end{array}$ & $1.08 \mathrm{nM}$ \\
\hline 3 & $\begin{array}{l}\text { 4a,6a-Dimethyl-2-oxo-N-(2,4,4-trimethyl-2-pentanyl)hexadecahydro-1H-indeno[5,4-f]quinoline- } \\
\text { 7-carboxamide }\end{array}$ & $0.495 \mathrm{nM}$ \\
\hline 4 & N-tert-butyl-1,4a,6a-trimethyl-2-oxohexadecahydro-1H-indeno[5,4-f]quinoline-7-carboxamide & $5.4 \mathrm{nM}$ \\
\hline 5 & 4-Azaandrostane-17-carboxamide, N,N-diethyl-4-methyl-3-oxo-, $(5 \alpha, 17 \beta)-$ & $19.8 \mathrm{nM}$ \\
\hline 6 & $\begin{array}{c}\text { (4aR,4bS,6aS,7S,9aS,9bS,11aR)-N,N-Diethyl-4a,6a-dimethyl-2-oxohexadecahydro-1H- } \\
\text { indeno[5,4-f]quinoline-7-carboxamide }\end{array}$ & $5.49 \mathrm{nM}$ \\
\hline 7 & 4a,6a-Dimethyl-7-(3-methylbutanoyl)hexadecahydro-2H-indeno[5,4-f]quinolin-2-one & $1.62 \mathrm{nM}$ \\
\hline 8 & 1,4a,6a-Trimethyl-7-(3-methylbutanoyl)hexadecahydro-2H-indeno[5,4-f]quinolin-2-one & $27 \mathrm{nM}$ \\
\hline 9 & 1,4a,6a-Trimethyl-7-(2-methylbutanoyl)hexadecahydro-2H-indeno[5,4-f]quinolin-2-one & $45 \mathrm{nM}$ \\
\hline 10 & 4a,6a-Dimethyl-7-(2-methylbutanoyl)hexadecahydro-2H-indeno[5,4-f]quinolin-2-one & $6.84 \mathrm{nM}$ \\
\hline
\end{tabular}
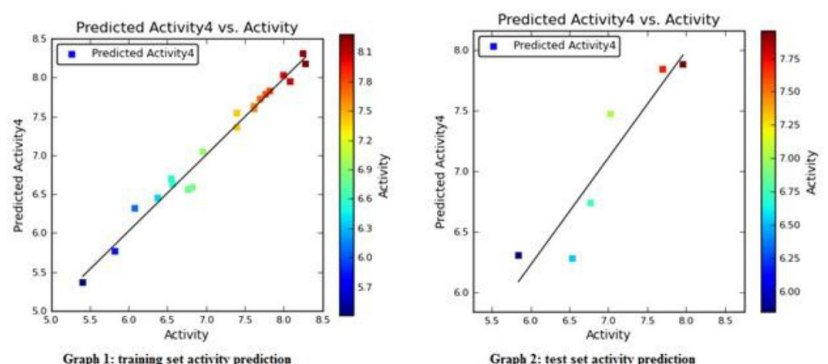

Figure 3: Graph of test and training set.

\section{CONCLUSION}

The squared correlation coefficient for the test set and training set was observed to be 0.87 and 0.96 respectively (actual $\mathrm{v} / \mathrm{s}$ predicted values) (Figure 3). The model could be used to design potent inhibitors against $5 \mathrm{a}$.

\section{ACKNOWLEDGMENT}

The authors would like to acknowledge the facilities provided by the Manipal College of Pharmaceutical Sciences and Manipal Academy for Higher Education in executing this research work.

\section{CONFLICT OF INTEREST}

None.

\section{ABBREVIATIONS}

T: Testosterone; DHT: Dihydrotestosterone; 5aR: 5a-reductase; QSAR: Quantitative structure-activity relationship; $\mathrm{IC}_{50}$ : Half-maximal inhibitory concentration;
OPLS: Optimized Potential for Liquid Simulations; A: H-bond acceptor; H: Hydrophobic group; PLS: Partial least square.

\section{REFERENCES}

1. Feder H. Hormones and sexual behavior. Annu Rev Psychol. 1984;35(1):165-200.

2. Thomson AA, Foster BA, Cunha GR. Analysis of growth factor and receptor mRNA levels during development of the rat seminal vesicle and prostate. Development. 1997;124(12):2431-9.

3. Cilotti A, Danza G, Serio M. Clinical application of 5a-reductase inhibitors. J Endocrinol Invest. 2001;24(3):199-203.

4. Andersson S, Russell DW. Structural and biochemical properties of cloned and expressed human and rat steroid 5 alpha-reductases. Proceedings of the National Academy of Sciences. 1990;87(10):3640-4.

5. Li X, Chen C, Singh SM, Labire F. The enzyme and inhibitors of 4-ene-3oxosteroid 5a-oxidoreductase. Steroids. 1995;60(6):430-41.

6. Guarna A, Belle C, Machetti F, Occhiato EG, Payne AH, Cassiani C, et al. 19-Nor-10-azasteroids: a novel class of inhibitors for human steroid 5a-reductases 1 and 2. J Med Chem. 1997;40(7):1112-29.

7. Canguven $\mathrm{O}$, Burnett AL. The effect of 5 a-reductase inhibitors on erectile function. J Androl. 2008;29(5):514-23.

8. Thorpe A, Neal D. Benign prostatic hyperplasia. The Lancet. 2003;361 (9366):1359-67.

9. Salem OI, Frotscher M, Scherer C, Neugebauer A, Biemel K, Streiber M, et al. Novel 5a-reductase inhibitors: synthesis, structure- activity studies,and pharmacokinetic profile of phenoxybenzoylphenyl acetic acids. J Med Chem. 2006;49(2):748-59.

10. Finn DA, Beadles-Bohling AS, Beckley EH, Ford MM, Gililland KR, GorinMeyer RE, et al. A new look at the 5a-reductase inhibitor finasteride. CNS Drug Rev. 2006;12(1):53-76.

11. Aggarwal S, Thareja S, Verma A, Bhardwaj TR, Kumar M. An overview on 5a-reductase inhibitors. Steroids. 2010;75(2):109-53.

12. Stoner E, Group FS. The clinical effects of a $5 a$-reductase inhibitor, finasteride, on benign prostatic hyperplasia. J Urol. 1992;147(5):1298-302.

13. Sun Z-Y, Wu H-Y, Wang M-Y, Tu Z-H. The mechanism of epristeride against benign prostatic hyperplasia. Eur J Pharmacol. 1999;371(2):227-33.

14. Gormley GJ, Stoner E, Bruskewitz RC, Imperato-McGinley J, Walsh PC, McConnell JD, et al. The effect of finasteride in men with benign prostatic hyperplasia. N Engl J Med. 1992;327(17):1185-91. 
15. Hirosumi J, Nakayama O, Chida N, Inami M, Fagan T, Sawada K, et al. FK143, a novel nonsteroidal inhibitor of steroid 5a-reductase:(2) In vivo effects on rat and dog prostates. J Steroid Biochem Mol Biol. 1995;52(4):365-73.

16. Sawada K, Okada S, Golden P, Kayakiri N, Sawada Y, Hashimoto M, et al. 4-(1-Benzoylindol-3-yl) butyric acids and FK143: novel nonsteroidal inhibitors of steroid 5a-reductase (II). Chem Pharm Bull. 1999;47(4):481-91.

17. Lesuisse D, Gourvest J-F, Albert E, Doucet B, Hartmann C, Lefrançois J-M, et al. Biphenyls as surrogates of the steroidal backbone. Part 2: Discovery of a novel family of non-steroidal 5- $\alpha$-reductase inhibitors. Bioorg Med Chem Lett. 2001;11(13):1713-6.

18. Baston E, Salem OI, Hartmann RW. Cyclohex-1-ene Carboxylic Acids: Synthesis and Biological Evaluation of Novel Inhibitors of Human $5 \mathrm{a}$ Reductase. Arch Pharm. 2003;336(1):31-8.
19. Rasmusson GH, Reynolds GF, Steinberg NG, Walton E, Patel GF, Liang T, et al. Azasteroids: structure-activity relationships for inhibition of 5 . alpha.-reductase and of androgen receptor binding. J Med Chem. 1986;29(11):2298-315.

20. Liang T, Heiss CE. Inhibition of 5 alpha-reductase, receptor binding and nuclear uptake of androgens in the prostate by a 4-methyl-4-aza-steroid. Jour of Bio Chem. 1981;256(15):7998-8005.

21. Pai V, Muddukrishna B, Pai A. Computational approach for the design of novel tankyrase inhibitors: a rational study based on pharmacophore and atom based 3D QSAR. Res Jour of Pharm and Tech. 2017;10(3):778-84.

\section{PICTORIAL ABSTRACT}

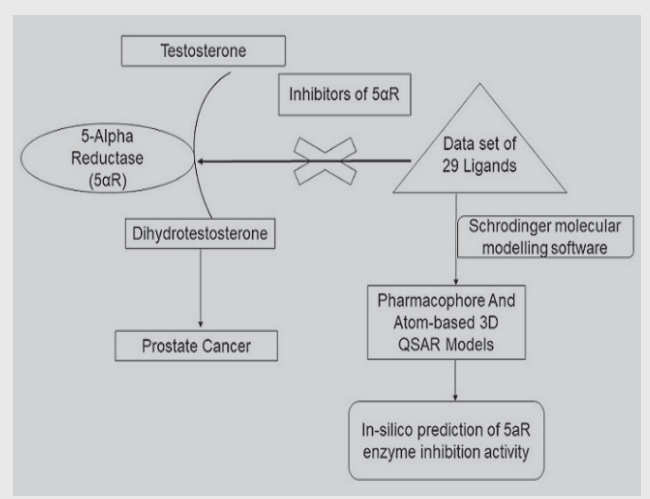

\section{About Authors}
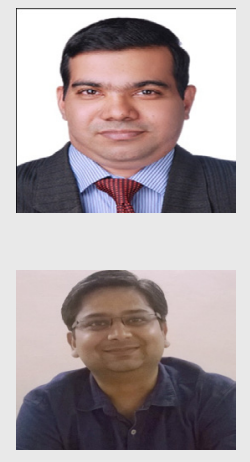
Current Traditional Medicine. androgen signalling pathway.

\section{Summary}

- The primary male sex hormone, testosterone $(T)$ is improved to a metabolite in cells by 5 a-reductase (5aR) type II enzyme. A metabolite is dihydrotestosterone which is more potent than T.

- Drug therapy act by dropping the DHT formation through inhibiting the $5 \mathrm{aR}$ enzyme.

- Thus, this research work was undertaken to design a novel $5 \mathrm{aR}$ enzyme inhibitor by pharmacophore and Atom-based 3D QSAR technique.

- A dataset of twenty-nine ligands available with IC 50 chosen from literature. Schrodinger molecular modeling software is having, Phase 3.0 module implicated for generation of pharmacophore models.

- The hypothesis resulted into statistically significant three-dimensional QSAR model. The statistical parameters were found to be 0.9804 as $\mathrm{r}^{2}$ value and 0.8321 as q $^{2}$ value.

- The 5aR enzyme inhibitors can be analyzed In-silico to predict requirements of the ligands by this built model.

Dr Richard Lobo: is an Associate Professor Senior Scale, Department of Pharmacognosy, Manipal College of Pharmaceutical Sciences, Manipal Academy of Higher Education, Manipal. $\mathrm{He}$ is actively involved in natural and semisynthetic research work, published more than 70 research papers in various national and international journals. He is also serving as Associate Editor for BMC Complementary and Alternative Medicine and Editorial board member for

Mr Abhishek Shah: is an Ph.D. Research Scholar from Department of Pharmacognosy, Manipal College of Pharmaceutical Sciences, MAHE, Manipal. Currently working in the area of molecular docking of natural compound and pharmacological screening of molecules by

Cite this article: Shah A, Lobo R, Nandakumar K, Pai A. Pharmacophore and Atom Based 3D QSAR Studies on the Novel 5-Alpha-Reductase Inhibitors. Indian J of Pharmaceutical Education and Research. 2018;52(4 Suppl 2): S296-S302. 